\title{
Partial liquid ventilation improves lung function in ventilation- induced lung injury
}

\author{
G.F. Vazquez de Anda*,\#, R.A. Lachmann*, S.J.C. Verbrugge*, D. Gommers*, J.J. Haitsma*, \\ B. Lachmann*
}

\begin{abstract}
Partial liquid ventilation improves lung function in ventilation-induced lung injury. G.F. Vazquez de Anda, R.A. Lachmann, S.J.C. Verbrugge, D. Gommers, J.J. Haitsma, B. Lachmann. C) ERS Journals Ltd 2001.

ABSTRACT: Disturbances in lung function and lung mechanics are present after ventilation with high peak inspiratory pressures (PIP) and low levels of positive endexpiratory pressure (PEEP). Therefore, the authors investigated whether partial liquid ventilation can re-establish lung function after ventilation-induced lung injury.

Adult rats were exposed to high PIP without PEEP for $20 \mathrm{~min}$. Thereafter, the animals were randomly divided into five groups. The first group was killed immediately after randomization and used as an untreated control. The second group received only sham treatment and ventilation, and three groups received treatment with perfluorocarbon $\left(10 \mathrm{~mL} \cdot \mathrm{kg}^{-1}, 20 \mathrm{~mL} \cdot \mathrm{kg}^{-1}\right.$, and $20 \mathrm{ml} \cdot \mathrm{kg}^{-1}$ plus an additional $5 \mathrm{~mL} \cdot \mathrm{kg}^{-1}$ after $\left.1 \mathrm{~h}\right)$. The four groups were maintained on mechanical ventilation for a further 2 -h observation period. Blood gases, lung mechanics, total protein concentration, minimal surface tension, and small/large surfactant aggregates ratio were determined.

The results show that in ventilation-induced lung injury, partial liquid ventilation with different amounts of perflubron improves gas exchange and pulmonary function, when compared to a group of animals treated with standard respiratory care. These effects have been observed despite the presence of a high intra-alveolar protein concentration, especially in those groups treated with 10 and $20 \mathrm{~mL}$ of perflubron.

The data suggest that replacement of perfluorocarbon, lost over time, is crucial to maintain the constant effects of partial liquid ventilation.
\end{abstract}

Eur Respir J 2001; 18: 93-99.

\begin{abstract}
*Dept of Anesthesiology, Erasmus University Rotterdam, Rotterdam, The Netherlands. " Unidad de Cuidados Intensivos, Hospital de Especialidades "Dr. Bernardo Sepulveda G.", del Centro Médico Nacional Siglo XXI, Instituto Mexicano del Seguro Social, México City, México.
\end{abstract}

Correspondence: B. Lachmann, Dept of Anesthesiology (Room Ee 2393), Erasmus University Rotterdam, PO Box 1738, 3000 DR Rotterdam, The Netherlands.

Fax: 31104089450

Keywords: Mechanical ventilation partial liquid ventilation

ventilation-induced lung injury

Received: March 42000

Accepted after revision January 30 2001

This work was financially supported by the International Foundation for Clinically Oriented Research (IFCOR), and $\mathrm{V}$. de Anda received a study grant from Consejo Nacional de Ciencia y Tecuología, Mexico. Equipment was made available by Siemens-Elema AB, Solna, Sweden.
It is known that modes of mechanical ventilation which allow end-expiratory alveolar collapse and/or end-inspiratory alveolar overstretching result in a decrease of lung compliance and gas exchange, and lead to atelectasis, pulmonary oedema, pneumonitis and fibrosis: for review see [1]. Development of intraalveolar protein-rich oedema in healthy rats subjected to intermittent positive pressure ventilation at high inflation pressures, without positive end-expiratory pressure (PEEP), was first demonstrated by WEBB and TIERNEY [2] and was later confirmed by DREYFUSS and coworkers [3,4] who suggested that high inspiratory lung volumes induce endothelial and epithelial overstretching leading to microvascular injury. Additionally, it is known that large changes in both volume and surface area result in surfactant depletion from the alveoli into the airways as well as to transformation from surface active large aggregates to inactive small aggregates [5-9]. Thus, loss of surfactant function will increase the surface tension at the air-liquid interface of the alveolar walls resulting in alveolar collapse and an increased suction force on the pulmonary interstitium which causes more alveolar oedema. The epithelial/endothelial damage results mainly from the shear forces which appear in a nonhomogeneous ventilated lung $[4,8]$.

It is known that perfluorocarbons (PFCs) have a surfactant-like activity due to their low surface tension $\left(18 \mathrm{mN} \cdot \mathrm{m}^{-1}\right)$, which in a surfactant-deficient lung decreases the high surface tension at the air-liquid interface [10-13]. Based on this low surface tension, the resulting peak inspiratory pressure (PIP) during volume-controlled ventilation are reduced $[10,11,13]$. Another property of PFCs is their high density which, mainly in the dependent part of the lung, recruits collapsed alveolar units [14, 15]; the combination of PFCs with gas ventilation, better known as partial liquid ventilation (PLV), also improves gas exchange in surfactant-deficient lungs $[10,11]$. Additionally, because PFCs might not be affected by the presence of 
plasma proteins in the alveolus, PFC might prove useful as a treatment for ventilation-induced injury $[16,17]$. Therefore, the aim of this study was to establish whether PLV can re-establish lung function in ventilation-induced lung injury (VILI).

\section{Material and methods}

\section{Animal preparation}

This study was approved by the local Animal Committee at the Erasmus University Rotterdam. The study was performed in 30 adult male SpragueDawley rats (body weight $280-350 \mathrm{~g}$ ). After induction of anaesthesia with $2 \%$ enflurane and $65 \%$ nitrous oxide in oxygen, a polyethylene catheter was inserted into a carotid artery for drawing arterial blood samples and continuous monitoring of arterial blood pressure. Before tracheotomy, the animals received $30 \mathrm{~mL} \cdot \mathrm{kg}^{-1}$ pentobarbital sodium, intraperitoneal (i.p.) (Nembutal (R, Algin BV, Maassluis, the Netherlands). After tracheotomy, muscle relaxation was induced by pancuronium bromide $0.6 \mathrm{~mL} \cdot \mathrm{kg}^{-1}$, intramuscular (i.m.) (Pavulon $\mathbb{R}$, Organon Teknika, Boxtel, the Netherlands) immediately followed by connection to a ventilator and a pressure transducer for continuous monitoring of arterial blood pressure. The animals were mechanically ventilated with a Servo Ventilator 300 (Siemens-Elema, Solna, Sweden) in a pressure constant time-cycled mode, at an inspired oxygen concentration $\left(F \mathrm{I}, \mathrm{O}_{2}\right)$ of 1.0 , frequency of 30 breaths per minute (bpm), PIP of $12 \mathrm{cmH}_{2} \mathrm{O}$, PEEP of $2 \mathrm{cmH}_{2} \mathrm{O}$, and inspiratory:expiratory (I:E) ratio of $1: 2$. Anaesthesia was maintained with pentobarbital sodium $30 \mathrm{~mL} \cdot \mathrm{kg} \cdot \mathrm{h}^{-1}$, i.p.; muscle relaxation was maintained with pancuronium bromide $0.6 \mathrm{~mL} \cdot \mathrm{kg} \cdot \mathrm{h}^{-1}$ i.m. Body temperature was kept within the normal range by means of a heating pad.

\section{Experimental design}

To produce ventilation VILI, PIP was increased to $45 \mathrm{cmH}_{2} \mathrm{O}$ and PEEP was decreased to zero for $20 \mathrm{~min}$, whereas the other ventilator settings were not changed. Thereafter, a 5-min period of hypoventilation was introduced (i.e. PIP decreased to $26 \mathrm{~cm} \mathrm{H}_{2} \mathrm{O}$ and PEEP increased to $6 \mathrm{cmH}_{2} \mathrm{O}$ ) to increase arterial carbon dioxide $\left(\mathrm{CO}_{2}\right)$. These ventilator settings were chosen based on a pilot study (unpublished data) which showed that animals ventilated at $45 / 0 \mathrm{cmH}_{2} \mathrm{O}$ (PIP/PEEP, respectively) for $20 \mathrm{~min}$ and then ventilated at $30 / 10 \mathrm{cmH}_{2} \mathrm{O}$ died from severe hypocapnia.

\section{Experimental groups}

The animals were randomized to one of five groups $(\mathrm{n}=6$ per group). In the first group (untreated controls), the animals were killed after the 5-min ventilation period of 26/6 (PIP/PEEP) with an overdose of pentobarbital. In each animal the thorax and diaphragm were opened, the tracheotomy catheter was connected to a pressure transducer and a pressure/volume curve (P/V curve) was immediately recorded (see later); thereafter a bronchoalveolar lavage (BAL) was performed five times with saline$\mathrm{CaCl}_{2}$ (see later). This group was used as an untreated control group. The second group (sham-treated controls) received a sham bolus of air $28 \mathrm{~mL} \cdot \mathrm{kg}^{-1}$ intratracheally and was mechanically ventilated at a PIP of $30 \mathrm{cmH}_{2} \mathrm{O}$, PEEP of $10 \mathrm{cmH}_{2} \mathrm{O}$, I:E ratio of $1: 2, \mathrm{FIO}_{2} 1.0$, and respiratory rate of $40 \mathrm{bpm}$ for $2 \mathrm{~h}$. These ventilator settings were chosen based on a preliminary study which showed that pressures of 26/6 $\mathrm{cmH}_{2} \mathrm{O}$ (PIP/PEEP, respectively) and 28/8 $\mathrm{cmH}_{2} \mathrm{O}$ were too low to keep animals alive for a 2 -h observation period. Three groups received $\mathrm{PFC}$ at a dose of $10 \mathrm{~mL} \cdot \mathrm{kg}^{-1}$ (PFC10), $20 \mathrm{~mL} \cdot \mathrm{kg}^{-1}$ (PFC20), or $20 \mathrm{~mL} \cdot \mathrm{kg}^{-1}$ plus after $60 \mathrm{~min}$, an extra dose of $5 \mathrm{~mL} \cdot \mathrm{kg}^{-1}(\mathrm{PFC} 20+\mathrm{R})$; this extra dose was based on a previous experience with this model (unpublished data) and aimed to maintain oxygen tension in arterial blood $\left(\mathrm{Pa}_{\mathrm{a}} \mathrm{O}_{2}\right)$ as stable as possible during the remainder of the study period.

\section{Treatment with perfluorocarbons}

The PFC used in this study (Liquivent $\mathbb{R}$, Alliance Pharmaceutical, San Diego, CA, USA) is insoluble in water, has a specific gravity of $1.918 \mathrm{~g} \cdot \mathrm{cm}^{-1}$ at $25^{\circ} \mathrm{C}$, a surface tension of 18.1 dynes $\cdot \mathrm{cm}^{-1}$, vapour pressure of 3.6 torr $(0.5 \mathrm{kPa})$ at $20^{\circ} \mathrm{C}$ and 10.5 torr $(1.4 \mathrm{kPa})$ at $37^{\circ} \mathrm{C}$, an oxygen solubility of $53 \mathrm{~mL} \cdot 100 \mathrm{~mL}^{-1}$ and $\mathrm{CO}_{2}$ solubility of $210 \mathrm{~mL} \cdot 100 \mathrm{~mL}^{-1}$ at $37^{\circ} \mathrm{C}$, at 1 atmosphere pressure $[10,11]$. The groups $\mathrm{PFC} 10$ and PFC20 received a single dose of PFC intratracheally. The $\mathrm{PFC} 20+\mathrm{R}$ group received an initial dose of $20 \mathrm{~mL} \cdot \mathrm{kg}^{-1}$ of PFC and, after $60 \mathrm{~min}$, an extra dose of $5 \mathrm{~mL} \cdot \mathrm{kg}^{-1}$ of PFC was instilled intratracheally to compensate loss of PFC due to evaporation. At instillation, animals were disconnected from the ventilator and PFC was administered directly into the endotracheal tube over $3-5 \mathrm{~s}$; the animals were then immediately reconnected to the ventilator.

\section{Gas exchange and haemodynamics}

Arterial blood gas samples were taken in all groups before, after VILI, and at 5 min after the 26/6 period, and in the four ventilated groups at 5 min after the 30/ 10 period, and at 30, 60, 90 and 120 min after PFC instillation. The samples were analysed for $\mathrm{Pa}_{\mathrm{a}} \mathrm{O}_{2}$ and arterial carbon dioxide tension $\left(\mathrm{Pa}_{\mathrm{a}} \mathrm{CO}_{2}\right)$ by conventional methods (ABL 505, Radiometer, Copenhagen, Denmark). At the same time points, arterial pressure was recorded. Haemodynamic support was provided by infusion of $1 \mathrm{~mL}$ of saline (to a maximum of $2 \mathrm{~mL} \cdot \mathrm{h}^{-1}$ ) when mean arterial pressure (MAP) decreased $<60 \mathrm{mmHg}$.

\section{Pressure/volume curves}

At 120 min after administration of PFC all animals were killed with an overdose of pentobarbital sodium 
injected through the penile vein. Then static $\mathrm{P} / \mathrm{V}$ curves were recorded. After the thorax and diaphragm were opened (to eliminate the influence of chest wall compliance and intra-abdominal pressure), the tracheotomy catheter was connected to a pressure transducer (Validyne model DP 45-32, Validyne Engineering Co., Northridge, CA, USA) with a syringe attached to it, and pressures were recorded on a polygraph (Grass model 7B, Grass Instrument Co., Quincy, MA, USA). Using a syringe filled with nitrogen the lungs were first inflated (within $10 \mathrm{~s}$ ) to an airway pressure of $35 \mathrm{cmH}_{2} \mathrm{O}$, which was maintained for $5 \mathrm{~s}$, followed by deflation to an airway pressure of $0 \mathrm{cmH}_{2} \mathrm{O}$. Then the lungs were re-inflated in steps of $0.5 \mathrm{~mL}$ until an airway pressure of $35 \mathrm{cmH}_{2} \mathrm{O}$ was reached. Each inflation step took $1-2 \mathrm{~s}$ followed by a 5-s pause to allow pressure equilibration. After this, in the same way, the lungs were then deflated until an airway pressure of $0 \mathrm{cmH}_{2} \mathrm{O}$ was reached. The volume of nitrogen left in the syringe was recorded. The lower inflection point (LIP) was determined from the intersection of the lines representing the minimum slope of the compliance curve and the maximum slope of the compliance curve. Maximal compliance (Cmax) was calculated from the steepest part of the deflation limb [18]. Total lung capacity (TLC35) was defined as lung volume at inflation with a distending pressure of $35 \mathrm{cmH}_{2} \mathrm{O}$ [19].

\section{Gruenwald index}

The Gruenwald index which characterizes the surfactant system in situ [20], was calculated from the $\mathrm{P} / \mathrm{V}$ curve, defined as $(2 \mathrm{~V} 5+\mathrm{V} 10) / 2 \mathrm{~V} \max$, where $\mathrm{V} 5$, $\mathrm{V} 10$ and $\mathrm{Vmax}$ are the lung volumes at airway pressures of 5,10 and $35 \mathrm{cmH}_{2} \mathrm{O}$ from the deflation limb, respectively.

\section{Bronchoalveolar lavage}

After the $\mathrm{P} / \mathrm{V}$ curve recordings a BAL $\left(30 \mathrm{~mL} \cdot \mathrm{kg}^{-1}\right)$ was performed five times with saline- $\mathrm{CaCl}_{2}$ $1.5 \mathrm{mmol} \cdot \mathrm{L}^{-1}$. In the resultant $\mathrm{BAL}$ (crude lavage) there were two visible layers, the upper layer was composed of the saline-CaCl${ }_{2}$, oedema fluid and cell debris, and the bottom layer comprised only PFC. Thereafter, cell debris and PFC were removed from BAL by centrifugation at $400 \times g$ for $10 \mathrm{~min}$. The active surfactant component in the BAL fluid was separated from the nonactive surfactant component by differential centrifugation, followed by phosphorus analysis, and the ratio of nonactive to active (small to large aggregate) surfactant was calculated [21]. Finally, the protein concentration of the BAL fluid was determined using the Bradford method (Bio-Rad protein-assay, Munich, Germany) [22].

\section{Minimal surface tension}

Minimal surface tension of the crude lavage was determined by means of a modified Wilhelmy balance
(E. Biegler $\mathrm{GmbH}$, Mauerbach, Austria). In this method, a tight-fitting teflon barrier reduces the surface area of a teflon trough from $100-20 \%$ at a cycle speed of $0.33 \mathrm{~min}^{-1}$. Saline is used as subphase and is kept at $37^{\circ} \mathrm{C}$. The force on a platinum slide $(1 \times 1 \mathrm{~cm})$ is measured by a force transducer and expressed as surface tension. Further, maximal surface tension is measured at $100 \%$ surface area and minimal surface tension at $80 \%$ surface compression and expressed as milli Newton $\cdot \mathrm{metre}^{-1}\left(\mathrm{mN} \cdot \mathrm{m}^{-1}\right)$. Surface tension characteristics of a BAL sample are measured after application on the surface of the saline-filled trough. In this study $300 \mu \mathrm{L}$ of BAL fluid was applied to the surface of the trough; surface tension was measured after 3 cycles [23].

\section{Statistical analysis}

Statistical analysis was performed using the Instat 2.0 biostatistics package (GraphPad software, San Diego, CA, USA). Intragroup comparisons were analysed with repeated measures using analysis of variance (ANOVA); intergroup comparisons were analysed with ANOVA. If a difference was found, a post hoc test was performed (Tukey-Kramer). Statistical significance was accepted at p-values $<0.05$. All data are expressed as mean \pm standard deviation.

\section{Results}

Figure 1 shows the $\mathrm{Pa}, \mathrm{O}_{2}$ levels during the whole study period. After VILI and the ventilator settings were set at $26 / 6 \mathrm{cmH}_{2} \mathrm{O}$ for 5 min the $\mathrm{Pa}_{\mathrm{a}} \mathrm{O}_{2}$ decreased $<13.3 \mathrm{kPa}$ in all groups. After PFC instillation and

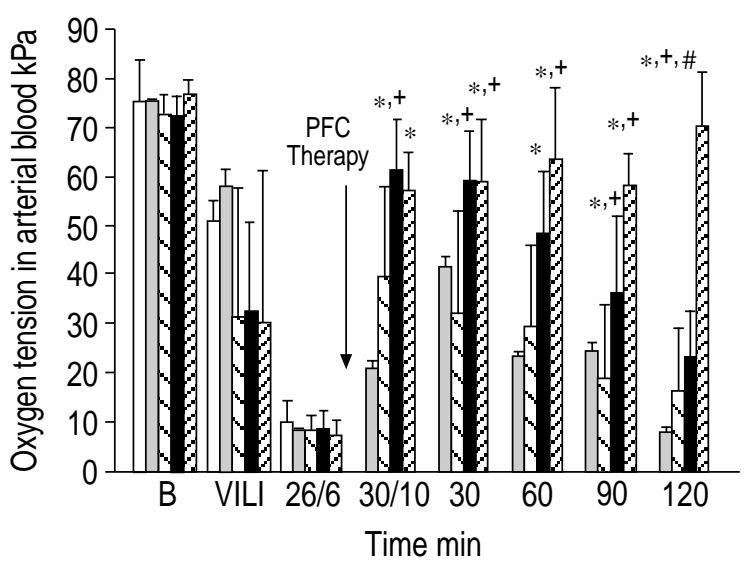

Fig. 1. - Arterial oxygen tension (mean \pm SD) during the whole study period. B: baseline; VILI: ventilation with peak inspiratory pressure (PIP) of $45 \mathrm{cmH}_{2} \mathrm{O}$ without peak end-expiratory pressure (PEEP) after $20 \mathrm{~min}$; 26/6: after $5 \mathrm{~min}$ at PIP $26 \mathrm{cmH}_{2} \mathrm{O}$ PEEP; arterial carbon dioxide tension $\left(\mathrm{Pa}_{\mathrm{a}} \mathrm{O}_{2}\right)$ at $60 \mathrm{~min}$ in the group $\mathrm{PFC}_{20}+\mathrm{R}$ was measured before instillation of the additional $5 \mathrm{~mL}$ perflubron dose; PFC: perfluorobcarbons. PFC10: PFC at dose of $10 \mathrm{mg} \cdot \mathrm{kg}^{-1}$; PFC20: PFC at dose of $20 \mathrm{mg} \cdot \mathrm{kg}^{-1}$; PFC20+R: PFC at dose of $20 \mathrm{mg} \cdot \mathrm{kg}^{-1}$ plus $5 \mathrm{mg} \cdot \mathrm{kg}^{-1}$ after $60 \mathrm{~min}$ of ventilation. $\square$ : untreated; : sham-treated; $\square: \mathrm{PFC}_{10}$ : $\mathbf{\square}$ : PFC29; $\mathbb{Z}: \mathrm{PFC}_{20+\mathrm{R}}$. $*$ : significant difference with sham-treated control group; ${ }^{+}$: significant difference with PFC10, ${ }^{\#}$ : significant difference with PFC20. 
Table 1. - Data on arterial carbon dioxide tension $\left(\mathrm{Pa}_{\mathrm{a}} \mathrm{CO}_{2}\right)$ and mean arterial pressure (MAP) over time in both the treated and untreated groups

\begin{tabular}{lcccccc}
\hline & Time min & Untreated & Sham-Treated & PFC10 & PFC20 & PFC20+R \\
\hline${\mathrm{Pa}, \mathrm{CO}_{2} \mathrm{kPa}}^{*}$ & Baseline & $4.7 \pm 0.7$ & $5.3 \pm 1.6$ & $4.8 \pm 0.97$ & $4.9 \pm 0.8$ & $5.6 \pm 1.7$ \\
& VILI & $2.5 \pm 0.3$ & $2.4 \pm 0.6$ & $2.5 \pm 0.35$ & $2.7 \pm 0.4$ & $2.9 \pm 0.5$ \\
& $526 / 6$ & $4.7 \pm 0.7$ & $5.3 \pm 1.0$ & $5.0 \pm 2.1$ & $5.2 \pm 0.89$ & $6.7 \pm 1.7$ \\
& $530 / 10$ & & $5.3 \pm 1.3$ & $4.3 \pm 0.4$ & $4.8 \pm 0.7$ & $5.7 \pm 0.8$ \\
& 30 & $5.6 \pm 1.3$ & $3.9 \pm 0.4$ & $4.4 \pm 0.9$ & $5.4 \pm 0.9$ \\
& 60 & & $6.3 \pm 1.6$ & $4.4 \pm 1.3$ & $4.4 \pm 0.7$ & $4.7 \pm 1$ \\
& 90 & & $6.5 \pm 1.3$ & $4.8 \pm 1.2$ & $4.7 \pm 0.5$ & $5.6 \pm 0.8$ \\
$\mathrm{MAP} \mathrm{mmHg}$ & 120 & & $6.9 \pm 1.8$ & $4.8 \pm 2.1$ & $4.9 \pm 0.3$ & $4.4 \pm 0.9$ \\
& Baseline & $135 \pm 16$ & $134 \pm 15$ & $144 \pm 6$ & $140 \pm 24$ & $136 \pm 17$ \\
& VILI & $75 \pm 25$ & $84 \pm 32$ & $72 \pm 25$ & $85 \pm 22$ & $71 \pm 21$ \\
& $526 / 6$ & $74 \pm 30$ & $63 \pm 42$ & $47 \pm 24$ & $67 \pm 36$ & $89 \pm 32$ \\
& $530 / 10$ & & $111 \pm 12$ & $88 \pm 24$ & $106 \pm 25$ & $97 \pm 14$ \\
& 30 & & $81 \pm 24$ & $80 \pm 20$ & $89 \pm 21$ & $90 \pm 9$ \\
& 60 & & $89 \pm 19$ & $78 \pm 17$ & $95 \pm 15$ & $95 \pm 37$ \\
& 90 & & $89 \pm 29$ & $76 \pm 17$ & $97 \pm 15$ & $97 \pm 12$ \\
& 120 & & $85 \pm 9$ & $73 \pm 24$ & $80 \pm 13$ \\
\hline
\end{tabular}

Data are presented as mean \pm SD. Untreated: nonventilated control. Sham-treated is the Sham-treated, ventilated control; PFC10: partial liquid ventilation (PLV) with perfluorocarbons (PFC) at dose $10 \mathrm{mg} \cdot \mathrm{kg}^{-1}$; PFC20: PLV with PFC at dose $20 \mathrm{mg} \cdot \mathrm{kg}^{-1}$; PFC20+R: PLV with PFC at dose $20 \mathrm{mg} \cdot \mathrm{kg}^{-1}$ plus $5 \mathrm{mg} \cdot \mathrm{kg}^{-1}$ after $60 \mathrm{~min}$ of ventilation; VILI: ventilation induced lung injury; Baseline: measurement before VILI.

after increasing the pressures to $30 / 10 \mathrm{cmH}_{2} \mathrm{O}$ the $\mathrm{PFC}_{20}$ and $\mathrm{PFC} 20+\mathrm{R}$ groups showed a significant increase in $P \mathrm{a}, \mathrm{O}_{2}$ values to pre-VILI levels $(\mathrm{p}<0.001)$, but only the $\mathrm{PFC} 20+\mathrm{R}$ group maintained oxygen tension levels $>60 \mathrm{kPa}$ during the 2-h study period. In both groups with a single dose of PFC (PFC10 and PFC20) $\mathrm{Pa}_{2} \mathrm{O}_{2}$ values decreased over time. There were significant differences between the values in the ventilated and $\mathrm{PFC10}$ groups compared with the values of the $\mathrm{PFC} 20+\mathrm{R}$ throughout the study period $(\mathrm{p}<0.001)$.

Table 1 shows that the $\mathrm{Pa}_{\mathrm{a}} \mathrm{CO}_{2}$ values and MAP levels were comparable in all groups during the whole study period.

Table 2 shows data from BAL fluid and lung mechanics. Protein concentration was significantly higher in the PFC10 group compared with the untreated and the PFC20+R groups. The Gruenwald Index and the minimal surface tension of the crude lavage fluid from all ventilated groups were not significantly different from the untreated control group. For data on TLC35, Cmax, and LIP see table 2 and figures $2 \mathrm{a}$ and $\mathrm{b}$. The total phosphorous concentration in the BAL fluid was not different between groups. The ratio of small to large aggregates in BAL fluid was significantly higher in the four ventilated groups compared with the untreated control group, and there was no significant difference between the sham-treated control group and all the PFC-treated groups.

Figure $2 \mathrm{a}$ shows the inflation limbs from the P/V curves. Both PFC groups treated with $20 \mathrm{~mL} \cdot \mathrm{kg}^{-1}$ have a significantly lower opening pressure than both the untreated and the sham-treated control groups. The PFC20 + R group had a significantly higher TLC35 than both the untreated and sham-treated control groups. Figure $2 \mathrm{~b}$ shows the deflation limbs from the $\mathrm{P} / \mathrm{V}$ curves. The three PFC-treated groups had a

Table 2. - Amount of recovered bronchoalveolar ravage (BAL) fluid, protein concentration, lung volume above functional residual capacity at pressure $35 \mathrm{cmH}_{2} \mathrm{O}$ (TLC35), maximum compliance (Cmax), Gruenwald Index, lower inflection point of the pressure volume curve (LIP), minimal surface tension (min surf) of crude BAL fluid, total phosphorus concentration, and small aggregates (SA)/large aggregates (LA) ratio

\begin{tabular}{|c|c|c|c|c|c|}
\hline & Untreated & Sham-Treated & $\mathrm{PFC} 10$ & $\mathrm{PFC} 20$ & $\mathrm{PFC}_{20}+\mathrm{R}$ \\
\hline Recovery BAL fluid $\%$ & $90+1$ & $90+1$ & $90+1$ & $90+1$ & $90+1$ \\
\hline Protein concentration $\mathrm{BAL} \mathrm{mg} \cdot \mathrm{mL}^{-1}$ & $1.3 \pm 0.3 *$ & $1.4 \pm 0.4$ & $1.9 \pm 0.2$ & $1.8 \pm 0.3$ & $1.4 \pm 0.1^{*}$ \\
\hline TLC35 & $35 \pm 2 * *$ & $31 \pm 3^{*,+, * *}$ & $38 \pm 4$ & $39 \pm 4$ & $42 \pm 5$ \\
\hline $\mathrm{C} \max \mathrm{mL} \cdot \mathrm{kg}^{-1}$ & $1.5 \pm 0.3^{*,+, * *}$ & $1.4 \pm 0.2^{*,+, * *}$ & $2.4 \pm 0.2$ & $2.6 \pm 0.2$ & $2.8 \pm 0.6$ \\
\hline Gruenwald index & $0.30 \pm 0.09$ & $0.40 \pm 0.17$ & $0.40 \pm 0.07$ & $0.4 \pm 0.07$ & $0.5 \pm 0.2$ \\
\hline $\mathrm{LIP} \mathrm{cmH}_{2} \mathrm{O}$ & $15.3 \pm 1.4^{*,+, * *}$ & $18.2 \pm 2^{*,+, * *}$ & $10.8 \pm 1.2 * *$ & $10.6 \pm 3.3 * *$ & $6.7 \pm 1.9 *$ \\
\hline Min surf $\mathrm{mN} \cdot \mathrm{m}^{-1}$ & $33 \pm 3.1$ & $31 \pm 1.6$ & $35 \pm 2.1$ & $35 \pm 0.5$ & $32 \pm 3.9$ \\
\hline Total phosphorus mmol & $2.0 \pm 0.6$ & $1.4 \pm 0.5$ & $1.7 \pm 0.4$ & $1.5 \pm 0.3$ & $1.5 \pm 0.2$ \\
\hline SA/LA ratio & $1.7 \pm 1.1^{*,+, * *}$ & $4.6 \pm 2.7$ & $4.6 \pm 2.3$ & $5.6 \pm 3.5$ & $4.2 \pm 2.7$ \\
\hline
\end{tabular}

Values are presented as mean \pm SD. Untreated: nontreated, nonventilated control group; Sham-treated: Sham-treated, ventilated control group; PFC10: PFC $10 \mathrm{mg} \cdot \mathrm{kg}^{-1}$; PFC20: PFC $20 \mathrm{mg} \cdot \mathrm{kg}^{-1}$; PFC20+R: PFC $20 \mathrm{mg} \cdot \mathrm{kg}^{-1}+5 \mathrm{mg} \cdot \mathrm{kg}^{-1} \mathrm{after}$ $60 \mathrm{~min}$ of ventilation to replace PFC loss due to evaporation; PFC: perfluorobcarbons. *: versus $\mathrm{PFC} 10, \mathrm{p}<0.05$; $^{+}$: versus $\mathrm{PFC} 20, \mathrm{p}<0.05 ; * *$ versus $\mathrm{PFC} 20+\mathrm{R}, \mathrm{p}<0.05$ 

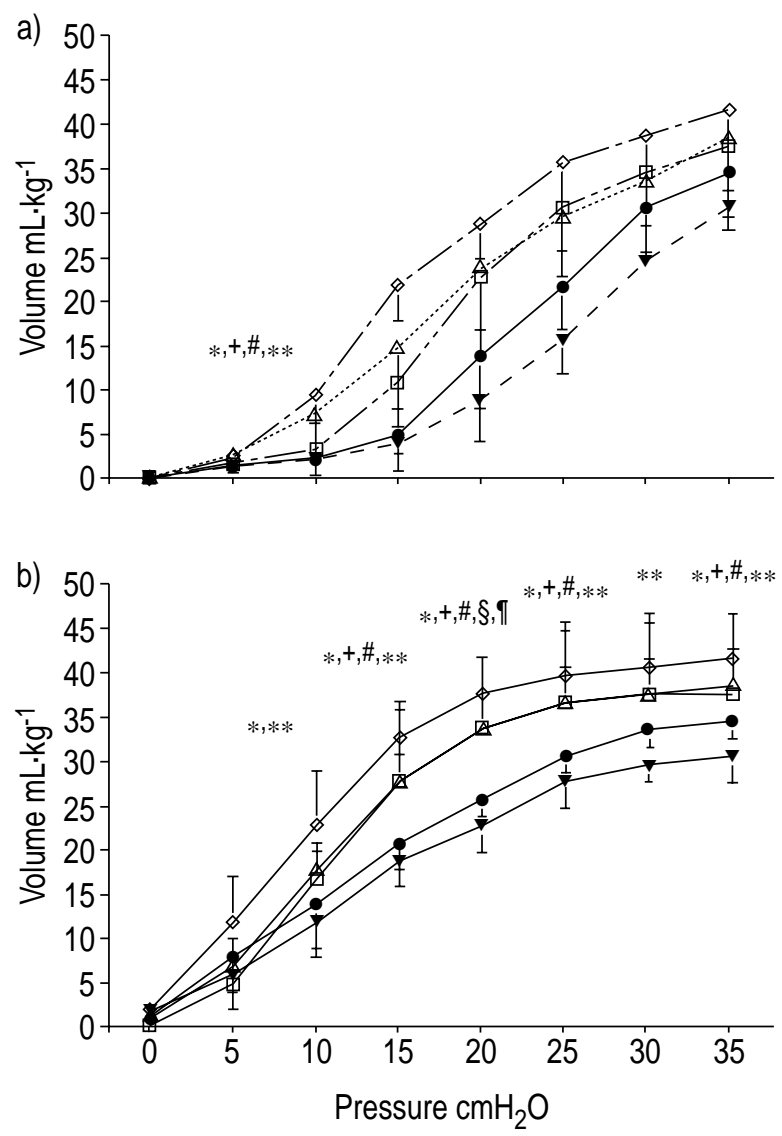

Fig. 2. - a) Inflation limbs from the pressure/volume curves $($ mean \pm SD). Untreated: untreated, nonventilated control group. Lower inflection point. b) Deflation limbs from the pressure/volume curves (mean $+\mathrm{SD}$ ). PFC10: $\mathrm{PFC}$ at dose of $10 \mathrm{mg} \cdot \mathrm{kg}^{-1} \mathrm{PFC}_{20}$ : PFC dose of $20 \mathrm{mg} \cdot \mathrm{kg}^{-1}$; $\mathrm{PFC} 20+\mathrm{R}$ : PFC dose at $20 \mathrm{mg} \cdot \mathrm{kg}^{-1}$ plus $5 \mathrm{mg} \cdot \mathrm{kg}^{-1}$ ventilation after $60 \mathrm{~min}$ of ventilation. 0 : untreated; $\boldsymbol{\nabla}$ : sham-treated; $\square$ : PFC10; $\triangle$ : PFC20; $\diamond: \mathrm{PFC}_{20+\mathrm{R}}{ }^{*}$ : significant differences between $\mathrm{PFC}_{20}+\mathrm{R}$ versus untreated; **: significant differences between $\mathrm{PFC}_{20}+\mathrm{R}$ versus sham-treated; ${ }^{+}$: significant differences between $\mathrm{PFC}_{20}$ versus sham-treated; ${ }^{\text {: }}$ PFC10 versus untreated; $\because$ : significant difference between PFC10 versus shamtreated; \$: significant difference between $\mathrm{PFC}_{20}$ versus untreated.

significantly higher $\mathrm{Cmax}$ than both untreated and the sham-treated control groups.

\section{Discussion}

This study shows that partial liquid ventilation improves $\mathrm{Pa}_{2} \mathrm{O}_{2}$ and lung mechanics in a model of ventilation-induced lung injury, despite the presence of a high intra-alveolar protein concentration. The authors have previously shown that this model of VILI is characterized by a decrease in lung mechanics and Gruenwald Index, and a high minimal surface tension in BAL fluid compared with healthy rat lungs [8]. The exact mechanism by which the lung damage is produced by artificial ventilation is not entirely clear, but the role of surfactant changes is being stressed [8, $9,16]$. The present group have shown that modes of ventilation with large tidal volume without PEEP disturb the surfactant system in a VILI model [8]. It has been demonstrated that loss of surface active molecules due to mechanical ventilation with high inspiratory lung volumes without PEEP is produced by displacement of surfactant from the alveolar airliquid interface into the small airways [2, 5]. Moreover, the surface area changes produced by the high inspiratory lung volumes lead to an increased rate of conversion of active into nonactive surfactant subtractions [7-9]. All these mechanisms will lead to alveolar collapse and protein infiltration $[2-4,8,9]$ in which the latter leads to further inactivation of surfactant [24, 25]. In the current study PLV was used to improve the disturbed lung function caused by VILI. The results showed that after VILI, PLV produced an immediate dose and time-dependent improvement in $\mathrm{Pa}, \mathrm{O}_{2}$. In the group treated with $10 \mathrm{~mL} \cdot \mathrm{kg}^{-1} \mathrm{PFC}$ the pre-VILI values of $\mathrm{Pa}, \mathrm{O}_{2}$ were never reached, whereas in both groups treated with $20 \mathrm{~mL} \cdot \mathrm{kg}^{-1} \mathrm{PFC}$, within $5 \mathrm{~min}$ there was a significant increase in $\mathrm{Pa}_{2} \mathrm{O}_{2}$ values compared with values after VILI, and these improved values were comparable with baseline values. However, $\mathrm{Pa}, \mathrm{O}_{2}$ decreased over time in both groups in which PFC was not replaced. It has been shown that in surfactant-deficient animal lungs PLV provides adequate gas exchange as long as a sufficient amount of PFC is present in the lungs $[10-13]$. The present group has demonstrated that higher doses of PFC lead to higher levels of oxygenation in animals suffering from acute respiratory failure as a result of dose-dependent recruitment of collapsed atelectatic alveoli by PFC $[10,11]$. It is also known that oxygenation deteriorates over time if no additional doses of PFC are instilled; this is attributed to evaporation of PFC which will cause affected alveoli to collapse [10, 11].

In the present study, the inflation limbs of the P/V curves showed on the one hand, a significantly lower opening pressure in the three PFC-treated groups and, on the other, a significantly higher maximal compliance compared with both control groups. It may be speculated that one of the reasons for this is that in the surfactant-deficient lungs, the decrease of surface tension at the air-liquid interface by PFC (vapour) improves the mechanical properties of the lung [10, $11,26-29]$. These findings have previously been demonstrated by KIRMSE et al. [14] showing that with increasing amounts of perflubron the LIP decreases to a point where additional doses of perflubron have no further influence on the detectable LIP.

A side-effect of PFC may be the constant surface tension which does not change with the changes in surface area (which is a property of natural surfactant) so that the end-expiratory stability in the PFCtreated animals (characterized by the Gruenwald Index) was not statistically different from the shamtreated control animals [13].

In the current study, the protein level from the crude BAL fluid in all ventilated groups was as high as in the untreated ventilated control group. Moreover, in both PFC-treated groups without replacement, an increase in the total protein concentration was observed. Additionally, the data show that with a larger amount of PFC $\left(\mathrm{PFC}_{20+\mathrm{R}}\right)$ in the lung, the total amount of protein in the BAL fluid is less. How 
PFC prevents protein infiltration and alveolar flooding is not entirely clear. DREYFuss et al. [26] showed in rats that PFC partially reversed the effects of alveolar flooding (the so-called tamponade effect), but in some rats, did not reduce the permeability changes on the alveolo-capillary membrane measured by ${ }^{125}$ I-labelled serum albumin. It has been suggested that as a result of the PFC-filled alveoli, the suction forces on the interstitium more or less disappear thus preventing protein influx into the PFC-filled alveoli. However, alveoli which have only a PFC film at the air-liquid interface and which may collapse during expiration will promote alveolar flooding due to their high surface tension at end-expiration; this could be one reason why the amount of proteins in the PFC group receiving only $10 \mathrm{~mL} \cdot \mathrm{kg}^{-1} \mathrm{PFC}$ is significantly higher than in the $\mathrm{PFC} 20+\mathrm{R}$ group.

In conclusion, the results of the present animal study show that in ventilator-induced lung injury, partial liquid ventilation with different amounts of perflubron improves gas exchange and pulmonary function, when compared to a group of animals treated with standard respiratory care. These effects have been observed despite the presence of a high intra-alveolar protein concentration, especially in those groups treated with 10 and $20 \mathrm{~mL}$ of perflubron. The data suggest that replacement of perfluorocarbon lost over time is crucial to maintain constant effects of partial liquid ventilation.

Acknowledgements. The authors thank S. Majoor and E. Hendrik for expert technical assistance, and the Depts of Cardiochemistry and Paediatrics at Erasmus University Rotterdam for assisting with phospholipid measurements. They would also like to thank L. Visser-Isles for the English-language editing.

\section{References}

1. Verbrugge SJ, Lachmann B. Mechanisms of ventilation-induced lung injury and its prevention: role of surfactant. Appl Cardiopulm Pathophysiol 1998; 7: $173-198$.

2. Webb H, Tierney D. Experimental pulmonary oedema due to high intermittent positive pressure ventilation with high inflation pressures. Protection by positive end expiratory pressure. Am Rev Respir Dis 1974; 110: $556-565$.

3. Dreyfuss D, Basset G, Soler P, Saumon G. Intermittent positive pressure hyperventilation with high inflation pressures produces pulmonary microvascular injury in rats. Am Rev Respir Dis 1985; 132: 880-884.

4. Dreyfuss D, Soler P, Basset G, Saumon G. High inflation pressure pulmonary oedema: respective effects of high airway pressure, high tidal volume, and positive end expiratory pressure. Am Rev Respir Dis 1988; 137: 1159-1164.

5. Faridy E. Effect of ventilation on movement of surfactant in airways. Respir Physiol 1975; 38: 461 466.

6. Ito Y, Veldhuizen R, Yaou L, McCraig L, Bartlett A, Lewis J. Ventilation strategies affect surfactant aggregate conversion in acute lung injury. Am $J$ Respir Crit Care Med 1997; 155: 493-499.

7. Ito Y, Manwell S, Kerr C, et al. Effects of ventilation on the efficacy of exogenous surfactant therapy in a rabbit model of acute lung injury. Am J Respir Crit Care Med 1998; 157: 149-155.

8. Verbrugge SJ, Böhm SH, Gommers D, Zimmerman L, Lachmann B. Surfactant impairment after mechanical ventilation with large alveolar surface area changes and effects of positive end-expiratory pressure. $\mathrm{Br}$ J Anaesth 1998; 80: 360-364.

9. Verbrugge SJ, Vazquez de Anda G, Gommers D, et al. Exogenous surfactant preserves lung function and reduces alveolar Evans blue dye influx in a rat model of ventilation-induced lung injury. Anaesthesiology 1998; 89: 467-474.

10. Tütüncü AS, Akpir K, Mulder P, Erdmann W, Lachmann B. Intratracheal perfluorocarbon administration as an aid in the ventilatory management of respiratory distress syndrome. Anaesthesiology 1993; 79: 1083 - 1093.

11. Tütüncü AS, Faithfull NS, Lachmann B. Intratracheal perfluorocarbon administration combined with artificial ventilation in experimental respiratory distress syndrome: dose dependent improvement of gas exchange. Crit Care Med 1993; 21: 962 - 969.

12. Hirschl RB, Tooley R, Parent A, Johnson K, Bartlett $\mathrm{R}$. Evaluation of gas exchange, pulmonary compliance, and lung injury during total and partial liquid ventilation in the acute respiratory distress syndrome. Crit Care Med 1996; 24: 1001 - 1008.

13. Verbrugge S, Lachmann B. Partial liquid ventilation. Eur Respir J 1997; 10: 1937-1939.

14. Kirmse M, Fujino Y, Hess D, Kacmarek R. Positive end-expiratory pressure improves gas exchange and pulmonary mechanics during partial liquid ventilation. Am J Respir Crit Care Med 1998; 158: $1550-$ 1556.

15. Quintel M, Hirschl R, Roth H, Loose R, Van Ackern $\mathrm{K}$. Computer tomographic assessment of perfluorocarbon and gas distribution during partial liquid ventilation for acute respiratory failure. Am J Respir Crit Care Med 1998; 158: 249-255.

16. Dreyfuss D, Saumon G. Ventilator induced lung injury. Lessons from experimental studies. Am J Respir Crit Care Med 1998; 157: 294-323.

17. Gauger PG, Overbeck MC, Chambers SD, Cailipan CI. Partial liquid ventilation improves gas exchange and increases EELV in acute lung injury. $J$ Appl Physiol 1998; 84: $1566-1572$.

18. Gommers D, Vilstrup C, Bos $\mathrm{J}$, et al. Exogenous surfactant therapy increases static lung compliance, and cannot be assessed by measurements of dynamic compliance alone. Crit Care Med 1993; 21: $567-$ 574.

19. Lachmann B, Robertson B, Vogel J. In vivo lung lavage as an experimental model of the respiratory distress syndrome. Acta Anaesthesiol Scand 1980; 24: $231-236$.

20. Gruenwald P. A numerical index stability of lung expansion. J Appl Physiol 1963; 88: 359-367.

21. Veldhuizen RAW, Inchley K, Hearn SA, Lewis J, Possmayer F. Degradation of surfactant associated protein B (SP-B) during in vitro conversion of large into small surfactant aggregates. Biochem J 1993; 295 : $141-147$.

22. Bradford MM. A rapid and sensitive method for the 
quantitation of microgram quantities of protein utilizing the principle of protein dye binding. Ann Biochem 1976; 72 : $248-254$.

23. Eijking E, Gommers D, So K, de Maat M, Mouton J, Lachmann B. Prevention of respiratory failure after hydrochloric acid aspiration by intratracheal surfactant instillation in rats. Anesth Analg 1993; 76: 472-477.

24. Holm B, Enhorning G, Notter R. A biophysical mechanism by which plasma proteins inhibit surfactant activity. Chem Phys Lipids 1988; 49: 40-55.

25. Seeger W, Stohr G, Wolf H, Neuhof H. Alteration of surfactant function due to protein leakage: special interaction with fibrin monomer. J Appl Physiol 1985; 58: $326-338$.

26. Dreyfuss D, Martin-Lefèvre L, Saumon G. Hyperinflation-induced lung injury during alveolar flooding in rats. Effect of perfluorocarbon instillation. $\mathrm{Am}$ J Respir Crit Care Med 1999; 159: 1752-1757.

27. Kaisers U, Kuhlen R, Keske U, et al. Superimposing positive end-expiratory pressure during partial liquid ventilation in experimental lung injury. Eur Respir $J$ 1998; 11: $1035-1042$.

28. Hartog A, Kaisers U, Gommers D, Lachmann B. Comparing the effects of four different perfluorocarbons on gas exchange and lung mechanics in an animal model of acute lung injury. Appl Cardiopulm Pathophysiol 1999; 8: 41-46.

29. Hartog A, Vazquez de And G, Gommers D, et al. Comparison oexogenous surfactant therapy, mechanical ventilation with high end-expiratory pressure and partial liquid ventilation in a model of acute lung injury. Br J Anaesth 1999; 82: 81-86. 